\title{
Further Quantitative Structure-Cytotoxicity Relationship Analysis of 3-Styrylchromones
}

\author{
KOICHI TAKAO ${ }^{1}$, KAORI HOSHI $^{1}$, HIROSHI SAKAGAMI ${ }^{2}$, HAIXIA SHI ${ }^{2,3}$, KENJIRO BANDOW $^{4}$, JUNKO NAGAI $^{5}$, \\ YOSHIHIRO UESAWA ${ }^{5}$, AKITO TOMOMURA ${ }^{4}$, MINEKO TOMOMURA ${ }^{6}$ and YOSHIAKI SUGITA ${ }^{1}$ \\ ${ }^{1}$ Department of Pharmaceutical Sciences, Faculty of Pharmacy and Pharmaceutical Sciences, \\ Josai University, Saitama, Japan; \\ ${ }^{2}$ Meikai University Research Institute of Odontology (M-RIO), Saitama, Japan; \\ ${ }^{3}$ Shanghai Ninth People's Hospital, Shanghai Jiatong University School of Medicine, Shanghai, P.R. China; \\ ${ }^{4}$ Division of Biochemistry, Meikai University School of Dentistry, Saitama, Japan; \\ ${ }^{5}$ Department of Medical Molecular Informatics, Meiji Pharmaceutical University, Tokyo, Japan; \\ ${ }^{6}$ Department of Oral Health Sciences, Meikai University School of Sciences, Chiba, Japan
}

\begin{abstract}
Background/Aim: Very few studies are available about the biological activity of 3-styrylchromones. Our previous study demonstrated the importance of methoxy group at 6-position of the chromone ring and hydroxyl group at 4'position of phenyl group in styryl moiety. As a sequel of this study, we synthesized fourteen compounds that include eight 3-styrylchromones where methoxy group was introduced at 7position of chromone rings, and then evaluated their tumorspecificity. Materials and Methods: Tumor-specificity (TS) was calculated by relative cytotoxicity against human oral squamous cell carcinoma cell lines versus human normal oral cells. Apoptosis induction and growth arrest were monitored by cell-cycle analysis. Quantitative structure-activity relationship analysis of TS was performed with 3,167 chemical descriptors. Results and Discussion: Two compounds, 7methoxy-3-[(1E)-2-phenylethenyl]-4H-1-benzopyran-4-one [7] and 3-[(1E)-2-(4-hydroxyphenyl)ethenyl]-7-methoxy-4H-1benzopyran-4-one [14] showed higher tumor-specificity than doxorubicin and 5-FU, suggesting the importance of methoxy group in 7-position of the chromone ring. These compounds induced the apoptosis and mitotic arrest in HSC2 cells. The tumor-specificity of 3-styrylchromone derivatives were most correlated with descriptors for molecule shape and electronic charge. The present study suggested that
\end{abstract}

This article is freely accessible online.

Correspondence to: Hiroshi Sakagami, Meikai University Research Institute of Odontology (M-RIO), 1-1 Keyaki-dai, Sakado, Saitama 3500283, Japan. Tel: +81 492792758, e-mail: sakagami@dent.meikai.ac.jp

Key Words: 3-Styrylchromones, methoxy group, cytotoxicity, tumorspecificity, QSAR analysis, cell cycle analysis, molecular shape. modification by introducing methoxy group at 7-position, instead at 6-position, further increased the tumor-specificity of 3-styrylchromone.

Chromone is a two-ring backbone structure contained in many flavonoids. 3-Chromone is a compound that has a styryl group attached at 3-position of chromone. We previously reported that (E)-3-(4-hydroxystyryl)-6-methoxy-4H-chromen-4-one (compound A) showed approximately 69-fold higher cytotoxicity against human oral squamous cell carcinoma (OSCC) cell lines as compared with human normal oral cells (1). On the other hand, natural polyphenols such as tannins and flavonoids showed only marginal tumor-specificity $(2,3)$. As far as we are aware, only five studies of biological activities of 3-styrylchromone derivatives have been reported so far. This includes antimicrobial activity (4), antipicornavirus activity (5), free radical scavenging and $\alpha$ glucosidase inhibitory activity (6), apoptosis induction (7) and tumor-specificity (1).

Quantitative structure-activity relationship (QSAR) analysis demonstrated the importance of methoxy group at 6-position of the chromone ring and hydroxyl group at 4'position of phenyl group in styryl moiety (1). As a sequel of this study, we synthesized fourteen compounds that include eight 3-styrylchromones where methoxy group was introduced at 7-position of chromone ring, and then evaluated the tumor-specificity. We first investigated their cytotoxicity against four human oral squamous cell carcinoma (OSCC) cells lines (Ca9-22, derived from gingival tissue; HSC-2, HSC-3. HSC-4, derived from tongue) and three human normal oral mesenchymal cells [human gingival fibroblast (HGF), human periodontal ligamental fibroblast (HPLF) and human pulp cells (HPC)], and then performed QSAR analysis. 


\section{Materials and Methods}

Materials. Dulbecco's modified Eagle's medium (DMEM) was purchased from GIBCO BRL (Grand Island, NY, USA); fetal bovine serum (FBS), doxorubicin, 3-(4,5-dimethylthiazol-2-yl)-2,5diphenyltetrazolium bromide (MTT), ribonuclease A from SigmaAldrich Inc. (St. Louis, MO, USA); dimethyl sulfoxide (DMSO), actinomycin D (FUJIFILM Wako Chem., Osaka, Japan); 5-fluorouracil (5-FU) from Kyowa (Tokyo, Japan); $100 \mathrm{~mm}$ dishes from True Line (Nippon Genetics Co., Ltd., Tokyo, Japan) and 96-well plates from TPP (Techno Plastic Products AG, Trasadingen, Switzerland).

Synthesis of 3-Styrylchromones. Synthesis of test compounds. 3-[(1E)2-Phenylethenyl]-4H-1-benzopyran-4-one [1], 3-[(1E)-2-(4-fluorophenyl)ethenyl]-4H-1-benzopyran-4-one [2], 3-[(1E)-2-(4-chlorophenyl)ethenyl]-4H-1-benzopyran-4-one [3], 3-[(1E)-2-(4-dimethyaminophenyl)ethenyl]-4H-1-benzopyran-4-one [4], 6-methoxy-3-[(1E)-2phenylethenyl]-4H-1-benzopyran-4-one [5], 3-[(1E)-2-(4-dimethyaminophenyl)ethenyl]-6-methoxy-4H-1-benzopyran-4-one [6], 7methoxy-3-[(1E)-2-phenylethenyl]-4H-1-benzopyran-4-one [7], 3[(1E)-2-(4-fluorophenyl)ethenyl]-7-methoxy-4H-1-benzopyran-4-one [8], 3-[(1E)-2-(4-chlorophenyl)ethenyl]-7-methoxy-4H-1-benzopyran4-one [9], 3-[(1E)-2-(4-dimethyaminophenyl)ethenyl]-7-methoxy-4H1-benzopyran-4-one [10], 7-methoxy-3-[(1E)-2-(4-methoxyphenyl) ethenyl]-4H-1-benzopyran-4-one [11], 3-[(1E)-2-(3,4-dimethoxyphenyl) ethenyl]-7-methoxy-4H-1-benzopyran-4-one [12], 7-methoxy-3-[(1E)2-(3,4,5-trimethoxyphenyl)ethenyl]-4H-1-benzopyran-4-one [13] and 3-[(1E)-2-(4-hydroxyphenyl)ethenyl]-7-methoxy-4H-1-benzopyran-4one [14] were synthesized by Knoevenagel condensation of the appropriate 3-formylchromone with selected phenylacetic acid derivatives, according to previous methods (6). The compounds' structure is shown in Figure 1. All compounds were dissolved in DMSO at $40 \mathrm{mM}$ and stored at $-20^{\circ} \mathrm{C}$ before use.

Cell culture. Human OSCC cell lines (Ca9-22, HSC-2, HSC-3. HSC-4) and human normal oral mesenchymal cells (HGF, HPLF, HPC) (established in the Meikai University) at 10-18 population doubling levels were cultured at $37^{\circ} \mathrm{C}$ in DMEM supplemented with $10 \%$ heat-inactivated FBS, $100 \mathrm{U} / \mathrm{ml}$, penicillin $\mathrm{G}$ and $100 \mu \mathrm{g} / \mathrm{ml}$ streptomycin sulfate under a humidified $5 \% \mathrm{CO}_{2}$ atmosphere, as described previously $(7,8)$.

Assay for cytotoxic activity. Cells were inoculated at $6 \times 10^{3}$ cells $/ \mathrm{cm}^{2}$ in a 96-microwell plate. After $48 \mathrm{~h}$, the medium was replaced with fresh medium containing various concentrations of 3-styrylchromones $(0.3,0.6,1.3,3.1,6.3,12.5,25,50,100,200$ or $400 \mu \mathrm{M})$, doxorubicin $(0.078,0.16,0.31,0.63,1.25,2.5,5$ or $10 \mu \mathrm{M})$ or 5 -FU $(7.8,16,31$, $63,125,250,500$ or $1,000 \mu \mathrm{M})$. Cells were incubated for $48 \mathrm{~h}$ and the relative viable cell number was then determined in triplicate by the MTT method, as described previously $(7,8)$. Control cells were treated with the same amounts of DMSO and the cell damage induced by DMSO was subtracted. The concentration of compound that reduced the viable cell number by $50 \%\left(\mathrm{CC}_{50}\right)$ was determined from the dose-response curve.

Calculation of tumor-specificity index (TS). TS was calculated by the following equation: $\mathrm{TS}=$ Mean $\mathrm{CC}_{50}(\mathrm{HGF}+\mathrm{HPLF}+\mathrm{HPC}) /$ meanCC $_{50}\left(\mathrm{Ca} 9-22+\right.$ HSC-2 + HSC-3 + HSC-4) $(\mathrm{D} / \mathrm{B})$ or $\mathrm{CC}_{50}$ (HGF)/CC 50 (Ca9-22) [both derived from gingival tissue (9)] (C/A in Table I).

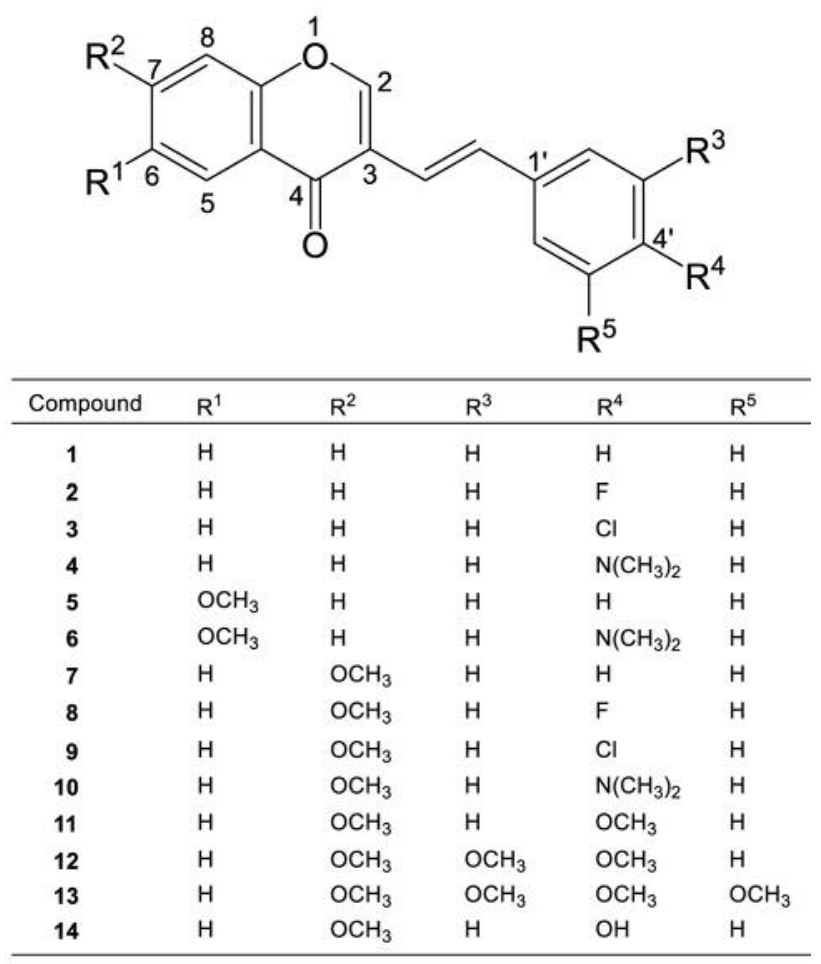

Figure 1. Structure of fourteen 3-styrylchromones [1-14] investigated in this study.

Calculation of potency-selectivity expression (PSE). PSE, that is the product of tumor-specificity and cytotoxicity against tumor cells, was calculated by the following equation: $\mathrm{PSE}=\left\{\right.$ Mean $\mathrm{CC}_{50}$ (normal cells)/[mean $\left.\mathrm{CC}_{50}(\mathrm{OSCC} \text { cell lines) }]^{2}\right\} \times 100$ [as shown in $\left(\mathrm{D} / \mathrm{B}^{2}\right) \times 100$ or $\left(\mathrm{C} / \mathrm{A}^{2}\right) \times 100$, Table I].

Cell-cycle analysis. Treated and untreated cells (approximately $10^{6}$ cells) were harvested from $100 \mathrm{~mm}$ dish, fixed, treated with ribonuclease $\mathrm{A}$, stained with propidium iodide, filtering through cell strainers and then subjected to cell sorting and cell-cycle analysis with Cell Sorter Software version 2.1.2. (SONY Imaging Products and Solution Inc., Tokyo, Japan), as described previously (8).

Estimation of $\mathrm{CC}_{50}$ values for computational analysis. The negative $\log \mathrm{CC}_{50}\left(\mathrm{pCC}_{50}\right)$ values for the comparison of cytotoxicity between compounds, as described previously (8). The mean $\mathrm{pCC}_{50}$ values for normal cells and tumor cell lines were defined as $\mathrm{N}$ and $\mathrm{T}$, respectively. The difference $(\mathrm{T}-\mathrm{N})$ was used as a tumor-specificity index.

Calculation of chemical descriptors. The 3D structure of each chemical structure (MarvinSketch 18.10.0, ChemAxon, Budapest, Hungary) (10), was optimized by CORINA Classic (Molecular Networks GmbH, Germany) (11) with forcefield calculations (amber-10: EHT) in Molecular Operating Environment (MOE) version 2019.0101 (Chemical Computing Group Inc., Quebec, Canada) (12). The number of structural descriptors calculated from 
Table I. Cytotoxic activity of fourteen 3-styrylchromones [1-14] against human oral squamous cell carcinoma (OSCC) cell lines and human oral normal cells. Each value represents the mean of triplicate determinations. Two sets of tumor-specificity index (TS) and potency-selectivity expression (PSE) values were determined as described in Materials and Methods.

\begin{tabular}{|c|c|c|c|c|c|c|c|c|c|c|c|c|c|c|c|}
\hline & \multicolumn{11}{|c|}{$\mathrm{CC}_{50}(\mu \mathrm{M})$} & & & & \\
\hline & \multicolumn{6}{|c|}{ Human oral squamous cell carcinoma cell lines } & \multicolumn{5}{|c|}{ Human normal oral cells } & \multirow{2}{*}{\multicolumn{2}{|c|}{$\mathrm{TS}$}} & \multirow{2}{*}{\multicolumn{2}{|c|}{ PSE }} \\
\hline & & HCC? & $\operatorname{HSC} 2$ & USC & & & & & & & & & & & \\
\hline & A & (n) & (1) & 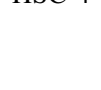 & B & S & C & 1 & (11) & D & ( & $\mathrm{D} / \mathrm{B}$ & $\mathrm{C} / \mathrm{A}$ & $\begin{array}{c}\left(\mathrm{D} / \mathrm{B}^{2}\right) \\
\times 100\end{array}$ & $\begin{array}{c}\left(\mathrm{C} / \mathrm{A}^{2}\right) \\
\times 100\end{array}$ \\
\hline 1 & 78.3 & 152.3 & 150.7 & 201.0 & 145.6 & 50.5 & 380.3 & 387.3 & 234.3 & 334.0 & 86.4 & 2.3 & 4.9 & 1.6 & 6.2 \\
\hline 2 & 19.6 & 17.0 & 23.6 & 19.6 & 20.0 & 2.7 & 21.6 & 23.6 & 23.4 & 22.9 & 1.1 & 1.1 & 1.1 & 5.7 & 5.6 \\
\hline 3 & 4.7 & 5.9 & 4.6 & 6.1 & 5.3 & 0.8 & 5.0 & 3.1 & 3.1 & 3.7 & 1.1 & 0.7 & 1.1 & 13.3 & 22.7 \\
\hline 4 & 9.2 & 5.5 & 20.0 & 24.5 & 14.8 & 8.9 & 400.0 & 3.4 & 27.0 & 143.5 & 222.5 & 9.7 & 43.5 & 65.6 & 472.6 \\
\hline 5 & 102.3 & 127.0 & 91.3 & 11.7 & 83.1 & 49.9 & 147.3 & 21.6 & 23.0 & 64.0 & 72.2 & 0.8 & 1.4 & 0.9 & 1.4 \\
\hline 6 & 7.5 & 3.1 & 6.2 & 9.4 & 6.5 & 2.6 & 6.8 & 5.2 & 6.3 & 6.1 & 0.8 & 0.9 & 0.9 & 14.2 & 11.9 \\
\hline 7 & 0.53 & 0.50 & 0.38 & 1.00 & 0.6 & 0.27 & 400.0 & 24.5 & 121.3 & 181.9 & 195.0 & 301.1 & 754.7 & 49842.4 & 142399.4 \\
\hline 8 & 1.09 & 0.93 & 0.79 & 1.51 & 1.1 & 0.31 & 5.9 & 3.1 & 3.1 & 4.1 & 1.6 & 3.7 & 5.4 & 346.2 & 493.6 \\
\hline 9 & 50.0 & 7.3 & 54.8 & 171.0 & 70.8 & 70.1 & 400.0 & 68.8 & 46.0 & 171.6 & 198.1 & 2.4 & 8.0 & 3.4 & 16.0 \\
\hline 10 & 24.3 & 11.1 & 23.2 & 78.2 & 34.2 & 29.9 & 400.0 & 15.9 & 53.6 & 156.5 & 211.7 & 4.6 & 16.4 & 13.4 & 67.6 \\
\hline 11 & 34.3 & 3.1 & 26.2 & 21.8 & 21.3 & 13.2 & 383.3 & 3.4 & 10.9 & 132.6 & 217.2 & 6.2 & 11.2 & 29.1 & 32.5 \\
\hline 12 & 21.0 & 18.6 & 21.3 & 19.0 & 20.0 & 1.4 & 400.0 & 32.9 & 116.0 & 183.0 & 192.5 & 9.2 & 19.0 & 45.9 & 90.7 \\
\hline 13 & 18.7 & 46.3 & 25.9 & 29.2 & 30.0 & 11.7 & 82.1 & 113.3 & 80.0 & 91.8 & 18.7 & 3.1 & 4.4 & 10.2 & 23.4 \\
\hline 14 & 0.64 & 1.12 & 0.32 & 0.54 & 0.65 & 0.34 & 283.3 & 33.0 & 40.0 & 118.8 & 142.6 & 182.0 & 445.0 & 27898.1 & 69899.4 \\
\hline DXR & 0.22 & 0.12 & 0.29 & 0.09 & 0.18 & 0.08 & 10.0 & 10.0 & 9.2 & 9.7 & 0.3 & 54.9 & 45.5 & 24953.8 & 20661.2 \\
\hline 5-FU & 37.7 & 187.7 & 14.2 & 7.8 & 61.8 & 84.9 & 1000.0 & 1000.0 & 1000.0 & 1000.0 & 0.0 & 16.2 & 26.5 & 26.2 & 70.5 \\
\hline
\end{tabular}

DXR: Doxorubicin; 5-FU: fluorouracil; Ca9-22: derived from gingival tissue; HSC-2, HSC-3 and HSC-4: derived from tongue.

MOE and Dragon (Dragon 7 version 7.0.2 (Kode srl., Pisa, Italy) (13) was 354 and 5,255 , respectively. As a result of excluding descriptors with a standard deviation of 0 , the number of descriptors used in this study was reduced to 307 in MOE and 2,860 in Dragon (Total: 3,167 ), respectively.

Statistical treatment. The $\mathrm{CC}_{50}$ values were expressed as mean \pm S.D. of triplicate assays. The relation among cytotoxicity, tumor-specificity index and chemical descriptors was investigated using simple regression analyses by JMP ${ }^{\circledR}$ Pro version 14.3.0 (SAS Institute Inc., Cary, NC, USA) (14). The significance level was set at $p<0.05$.

\section{Results}

Cytotoxicity and tumor-specificity. Among fourteen synthetic 3styrylchromone derivatives, [7] showed the highest cytotoxicity against four OSCC cell lines (mean $\left.\mathrm{CC}_{50}=0.60 \mu \mathrm{M}\right)(\mathrm{B}$ in Table I), followed by [14] $(0.65)>$ [8] (1.1) > [3] (5.3) > [6] (6.5) > [4] $(14.8)>[\mathbf{2}, \mathbf{1 2}](20.0)>[\mathbf{1 1}](21.3)>[\mathbf{1 3}](30.0)>[\mathbf{1 0}]$ $(34.2)>[9](70.8)>[5](83.1)>[1](145.6 \mu \mathrm{M})$. On the other hand, [3] showed the highest cytotoxicity against three normal oral mesenchymal cells (mean $\mathrm{CC}_{50}=3.7 \mu \mathrm{M}$ ) (D in Table I), followed by [8] (4.1) > [6] (6.1) > [2] (22.9) $>$ [5] (64.0) $>$ [13] $(91.8)>[14](118.8)>[11](132.6)>[4](143.5)>[10](156.5)$ $>$ [9] $(171.6)>$ [7] $(181.9)>[12](183.0)>$ [1] $(334.0 \mu \mathrm{M})$ (Table I).
When tumor-specificity (TS) was calculated by the ratio of mean $\mathrm{CC}_{50}$ for normal oral cells to that of OSCC cells (D/B in Table I), [7] showed the highest TS value (301.1), followed by [14] $(182.0)>[4](9.7)>[12](9.2)>[11](6.2)$ $>$ [10] (4.6) > [8] (3.7) > [13] (3.1) > [9] (2.4) > [1] (2.3) > [2] $(1.1)>$ [6] $(0.9)>$ [5] $(0.8)>[3](0.7)$.

The derivative [7] also showed the highest PSE value [(D/B $\left.{ }^{2}\right) x 100$ in Table I] (49842.4), followed by [14] (27898.1) $>$ [8] (346.2) > [4] (65.6) > [12] (45.9) > [11] (29.1) > [6] $(14.2)>[10](13.4)>[3](13.3)>[13](10.2)>[2](5.7)>[9]$ $(3.4)>[1](1.6)>[5](0.9)$. The prominent TS and PSE values of $[7,14]$ were again observed when Ca9-22 and HGF (both derived from gingival tissue) were used: 754.7, 445.0 (C/A) and $142399.4,69899.4$ [(C/A $\left.{ }^{2}\right) \times 100$ in Table I], respectively. Dose-response curves (Figure $2 \mathrm{~A}$ and $\mathrm{B}$ ) showed clearly that all OSCC cells (Ca9-22, HSC-2, HSC-3, HSC-4) were more sensitive to $[7,14]$ than normal oral cells (HGF, HPLF, HPC). It should be noted that TS and PSE values of $[7,14]$ were higher than doxorubicin ( $\mathrm{TS}=54.9,45.5$ : $\mathrm{PSE}=24953.8$, 20661.2) and 5-FU (TS=16.2, 26.5; PSE=26.2, 70.5) (Table I).

Cell-cycle analysis (Figure 3) demonstrated that both [7, 14] as well as actinomycin $D$ induced $s{ } G_{1}$ population, suggesting the apoptosis induction. It should be noted that $[7,14]$, but not actinomycin $D$, induced $G_{2}+M$ phase arrest. 

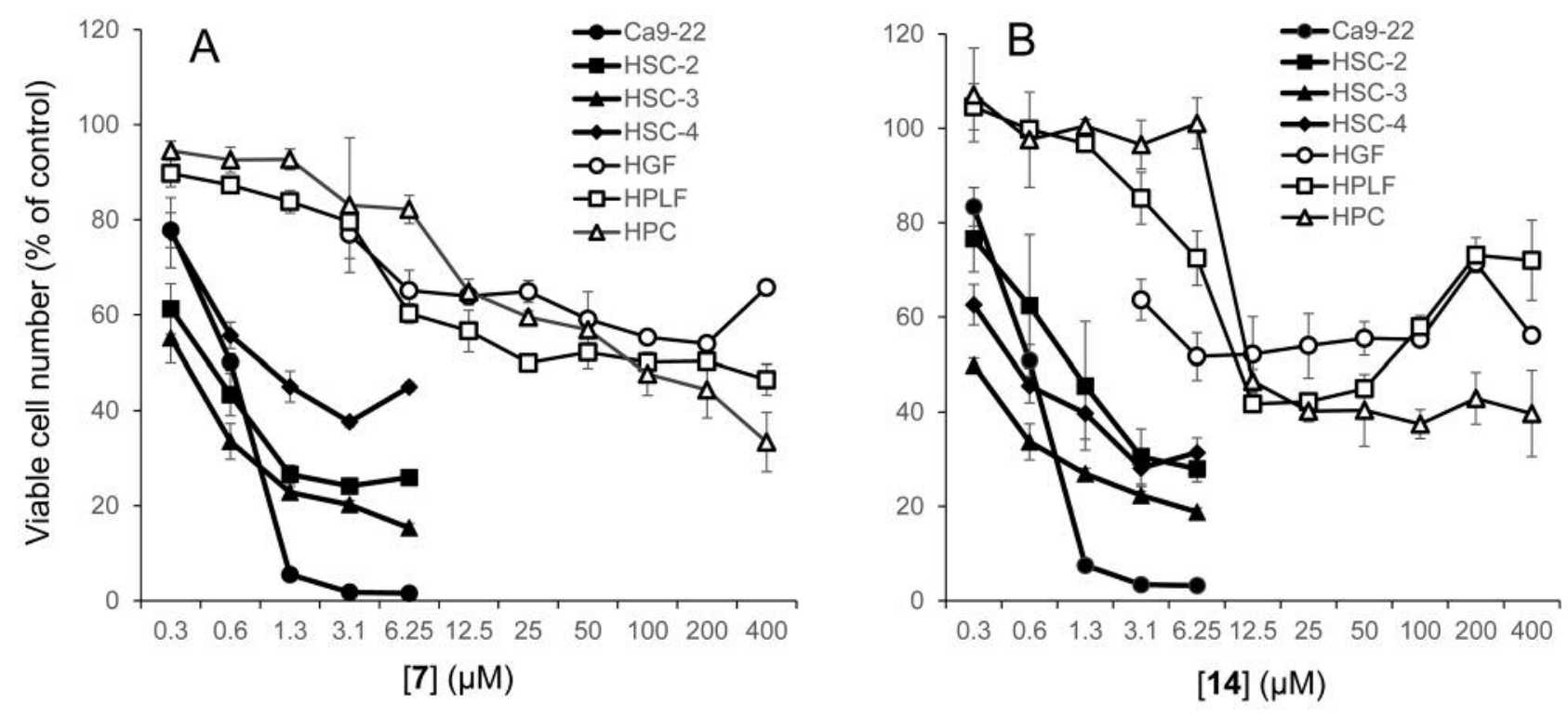

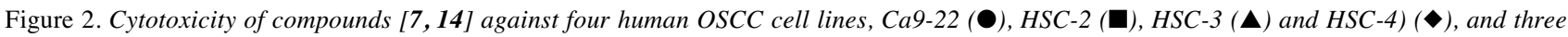
human normal mesenchymal oral cells, HGF $(\bigcirc), H P L F(\square)$ and $H P C(\triangle)$. Cells were incubated for 48 hithout (control) or with the indicated concentrations of [7] (A) or [14] (B), and cell viability was determined by MTT method, and expressed as percentage of control. Each value represents the mean $\pm S . D$. of triplicate assays.

Computational analysis. QSAR analysis of cytotoxicity and tumor-specificity of fourteen 3-styrylchromone derivatives [1-14] were next performed. Since a significant correlation $(p<0.05)$ was found between cytotoxicity against tumor and normal cells, and TS with 2,12 and 69 chemical descriptors (data not shown), top two or six chemical descriptors were chosen for QSAR analysis (Figures 4, 5 and 6, and Table II).

The cytotoxicity of 3-styrylchromone derivatives [1-14] against human OSCC cell lines was correlated positively with PJI3 (3D shape and size) $\left(\mathrm{r}^{2}=0.470, p=0.0068\right)$ while negatively with CIC1 (topological shape) $\left(\mathrm{r}^{2}=0.307\right.$, $p=0.0398$ ) (Figure 4)

The cytotoxicity of 3-styrylchromones [1-14] against normal oral cells was correlated positively with Petitjean (topological shape and size) $\left(r^{2}=0.373, \quad p=0.0203\right)$, SpMAD_AEA $(\mathrm{dm})$ (topological shape and dipole moment) $\left(\mathrm{r}^{2}=0.363, p=0.0226\right)$, BIC0 (topological shape) $\left(\mathrm{r}^{2}=0.321\right.$, $p=0.0346$ ) and JGI8 (topological shape and electric state) $\left(r^{2}=0.306, p=0.0402\right)$, while negatively with MATS4s (topological shape and electric state) $\left(\mathrm{r}^{2}=0.321, p=0.0348\right)$ and MATS4e (topological shape and electric state) $\left(r^{2}=0.319\right.$, $p=0.0355$ ) (Figure 5).

The TS of fourteen 3-styrylchromones [1-14] was correlated positively with MATS4e (topological shape and electric state) $\left(\mathrm{r}^{2}=0.414, p=0.0131\right), \mathrm{H} 8 \mathrm{~s}$ (3D shape) $\left(\mathrm{r}^{2}=0.404, p=0.0145\right)$, MNDO_LUMO (energy of the LUMO) $\left(\mathrm{r}^{2}=0.391, p=0.0168\right)$, and H8e (3D shape and electric state) $\left(\mathrm{r}^{2}=0.343, p=0.0276\right)$, while negatively with
AROM (aromaticity index) $\left(\mathrm{r}^{2}=0.349, p=0.0259\right)$, FASA_H (3D shape, size and partial charges) $\left(\mathrm{r}^{2}=0.346, p=0.0269\right)$ (Figure 6).

Tumor-specificity of [1-14] was reduced by the presence of methoxy group at R1 (6-position of chromone ring), but increased by the presence of methoxy group at R2 (7position of chromone ring) (Figure 7).

\section{Discussion}

The present study demonstrated that compounds 7-methoxy-3[(1E)-2-phenylethenyl]-4H-1-benzopyran-4-one [7] (TS=301.1 in $\mathrm{D} / \mathrm{B}, 754.7$ in $\mathrm{C} / \mathrm{A}$; $\mathrm{PSE}=49842.4$ in $100 \times \mathrm{D} / \mathrm{B}^{2}, 142399.4$ in $\left.100 \times \mathrm{C} / \mathrm{A}^{2}\right)$ and 3-[(1E)-2-(4-hydroxyphenyl)ethenyl]-7methoxy-4H-1-benzopyran-4-one [14] (TS=182.0, 445.0; $\mathrm{PSE}=27898.1,69899.4)$ showed higher tumor-specificity than with doxorubicin $(\mathrm{TS}=54.9,45.5$; $\mathrm{PSE}=24953.8,20661.2)$ and 5-FU (TS=16.2, 26.5; 26.2, 70.5) (Table I). This suggests the antitumor potential of $[7,14]$.

We previously reported that (E)-3-(4-hydroxystyryl)-6methoxy-4H-chromen-4-one (compound A) that have methoxy group at 6-position of the chromone ring and hydroxyl group at 4'-position of phenyl group in styryl moiety showed excellent tumor-specificity $[\mathrm{TS}=69.0 \mathrm{in} \mathrm{D} / \mathrm{B}$, 31.9 in $\mathrm{C} / \mathrm{A}$ ) (1); $\mathrm{PSE}=3,450$ in $100 \times \mathrm{D}^{-\mathrm{B}^{2}}$ ] (7). We found that [14] $(\mathrm{TS}=182.0)$ with methoxy group at 7-position showed higher tumor-specificity than compound A with methoxy group at 6-position $(\mathrm{TS}=69.0)(1)$. Similarly, the 
A
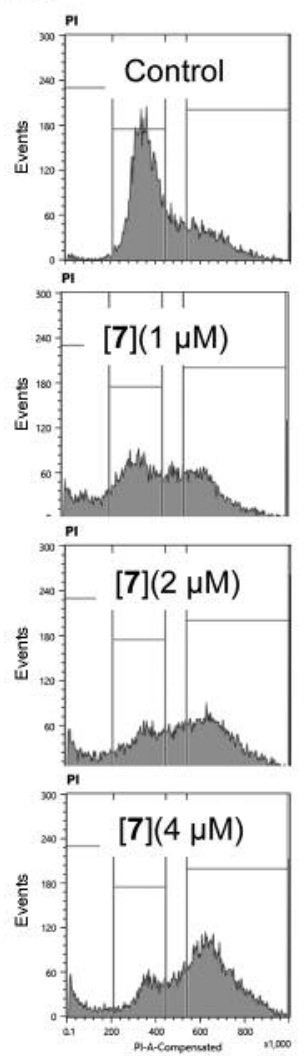
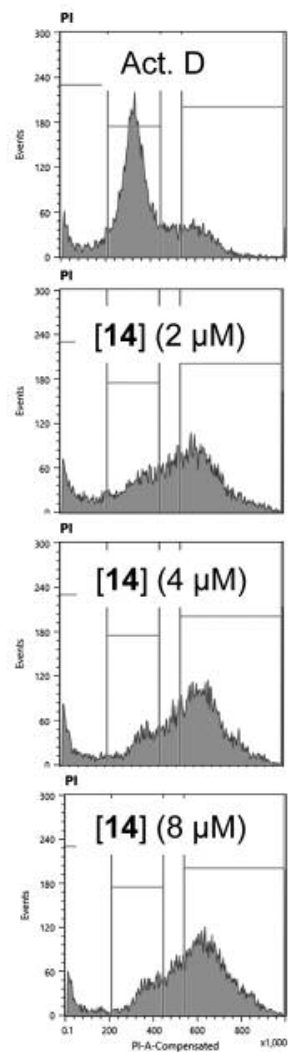

B

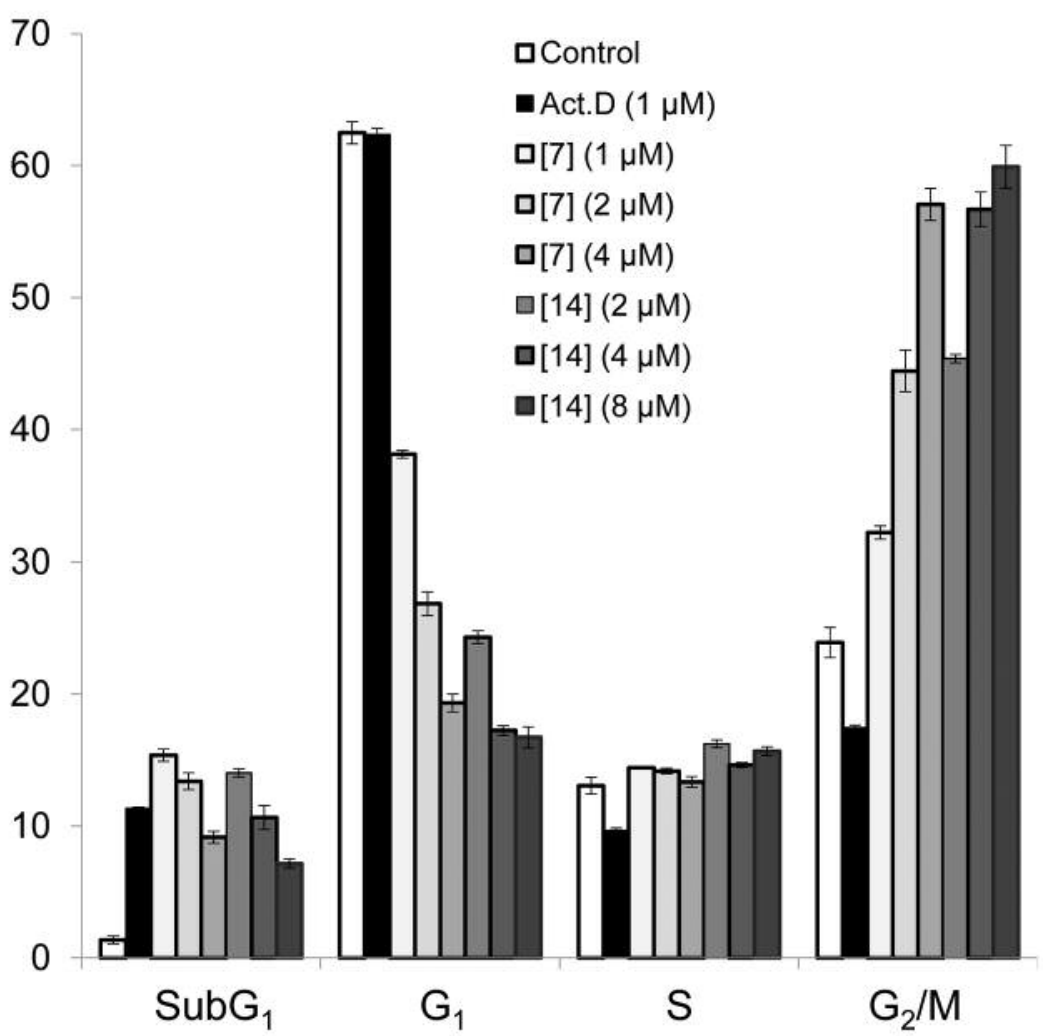

Figure 3. Effect of $[7,14]$ on cell-cycle distribution in HSC-2 cells. HSC-2 cells were incubated for 24 h with the indicated concentrations of [7], [14] or $1 \mu M$ actinomycin $D(A c t D)$ as a positive control and then assessed for cell-cycle distribution by a cell sorter.
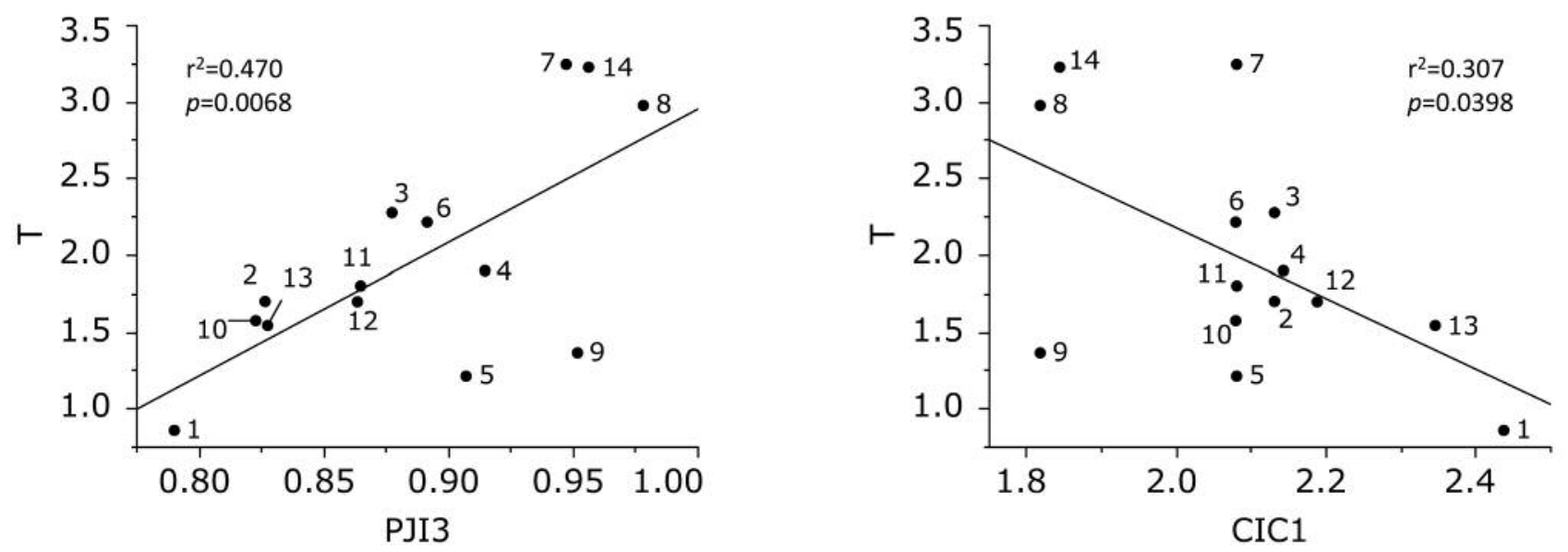

Figure 4. Two chemical descriptors that showed higher correlation with cytotoxicity of fourteen 3-styrylchromones [1-14] against OSCC cells. The mean negative log $C C_{50}$ values $(T)$ against tumor cells were plotted. $C C_{50}$ : concentration of compound that reduced the viable cell number by $50 \%$. PJI3 (3D shape and size $)\left(r^{2}=0.470, p=0.0068\right)$ and CIC1 (topological shape) $\left(r^{2}=0.307, p=0.0398\right)$. 

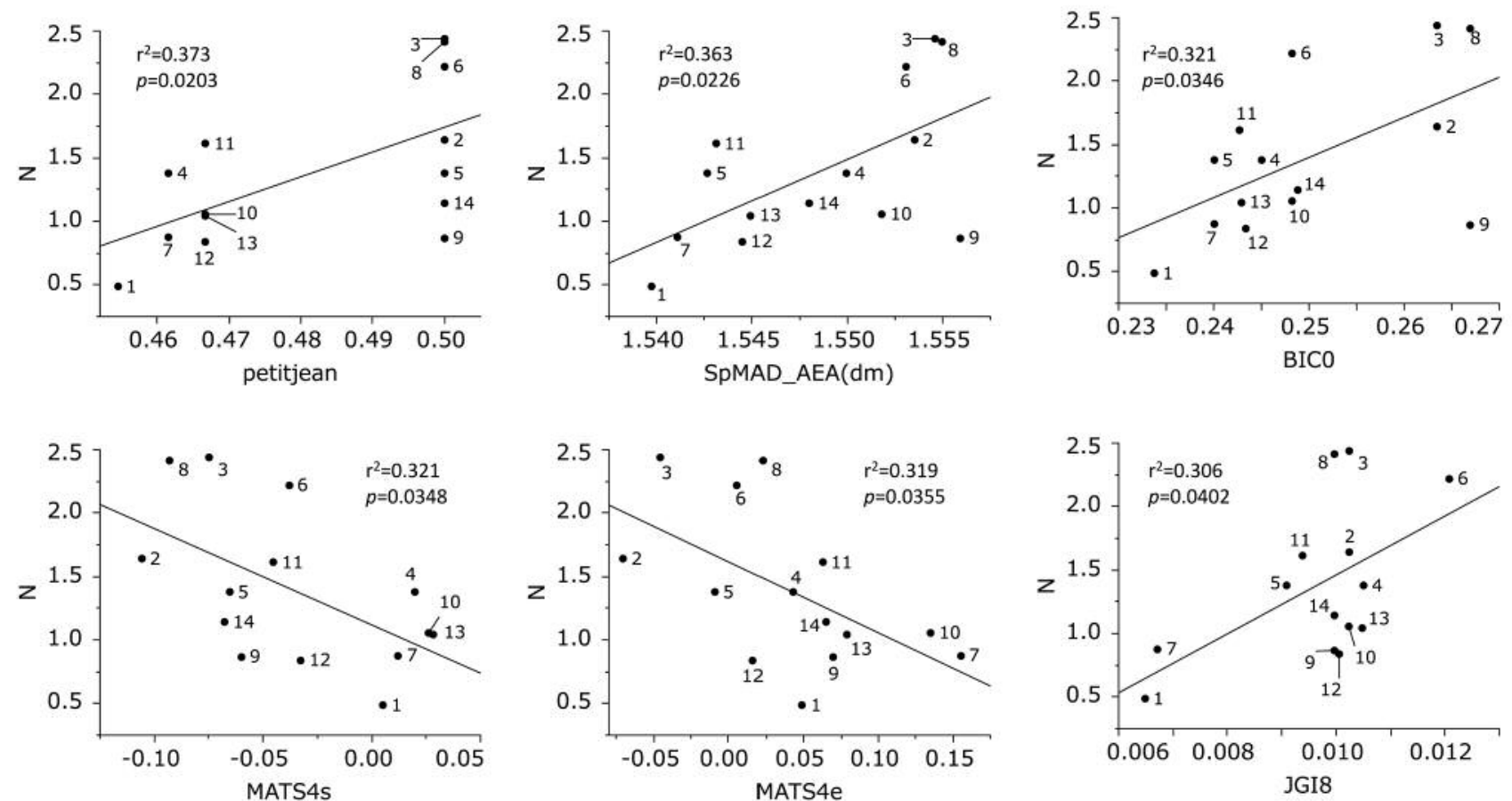

Figure 5. Top six chemical descriptors that showed higher correlation with cytotoxicity of fourteen 3-styrylchromones [1-14] against normal oral cells. The mean negative $\log C C_{50}$ values $(N)$ against normal cells were plotted. Top six chemical descriptors were: Petitjean (topological shape and size) $\left(r^{2}=0.373, p=0.0203\right)$, SpMAD_AEA(dm) (topological shape and dipole moment) $\left(r^{2}=0.363, p=0.0226\right)$, BICO (topological shape) $\left(r^{2}=0.321, p=0.0346\right)$, MATS4s (topological shape and electric state) $\left(r^{2}=0.321, p=0.0348\right)$, MATS4e (topological shape and electric state) $\left(r^{2}=0.319, p=0.0355\right)$ and JGI8 (topological shape and electric state) $\left(r^{2}=0.306, p=0.0402\right)$.
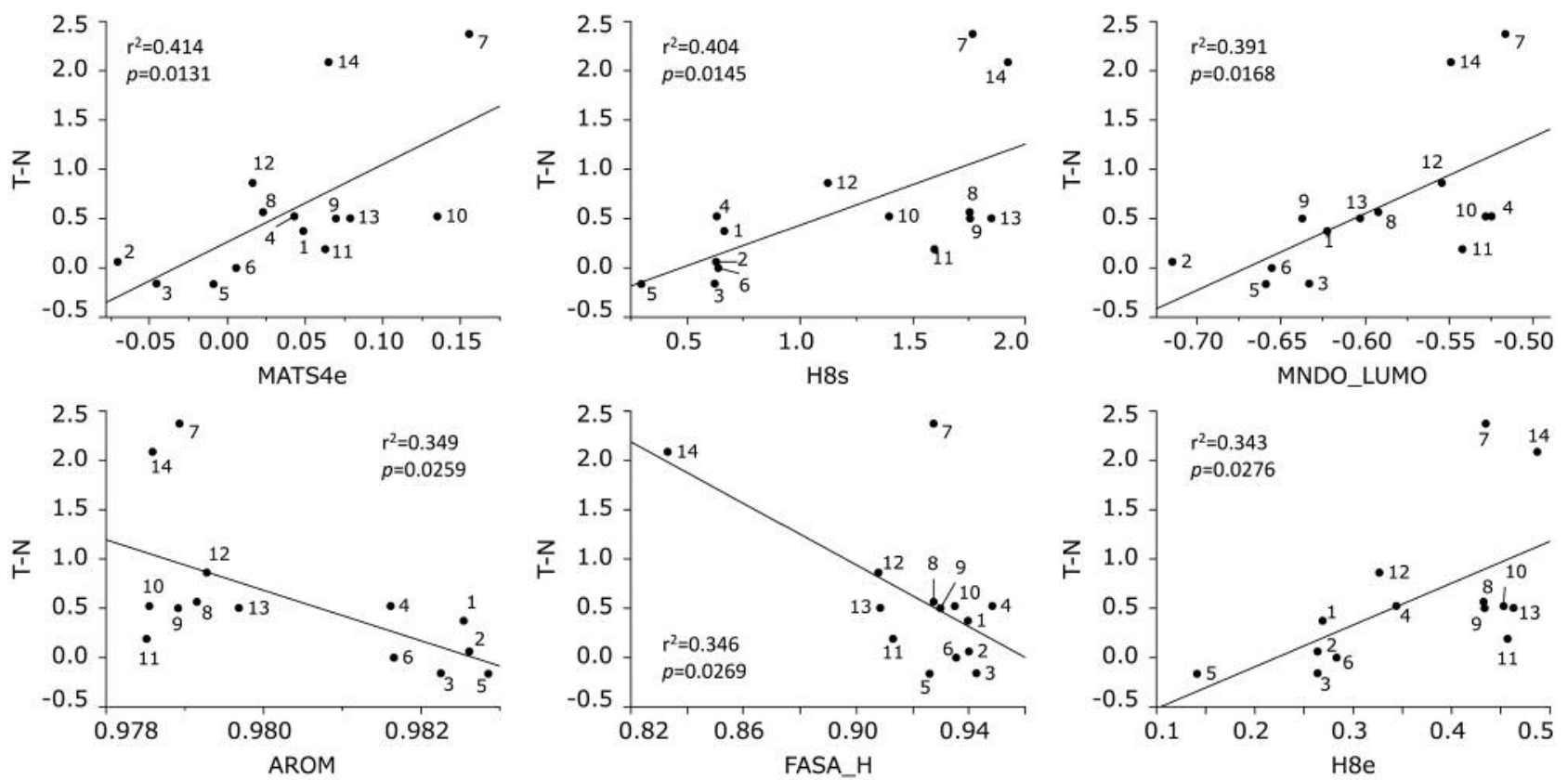

Figure 6. Top six chemical descriptors that showed higher correlation with tumor-specificity of fourteen 3-styrylchromones [1-14]. The mean negative $\log$ TS values (T-N) were plotted. Top six chemical descriptors were: MATS4e (topological shape and electric state) $\left(r^{2}=0.414, p=0.0131\right), \mathrm{H} 8 \mathrm{~s}$ (3D shape) $\left(r^{2}=0.404, p=0.0145\right)$, MNDO_LUMO (energy of the LUMO) $\left(r^{2}=0.391, p=0.0168\right)$, AROM (aromaticity index) $\left(r^{2}=0.349, p=0.0259\right)$, FASA_H (3D shape, size and partial charges) $\left(r^{2}=0.346, p=0.0269\right)$ and H8e $(3 D$ shape and electric state $)\left(r^{2}=0.343, p=0.0276\right)$. 


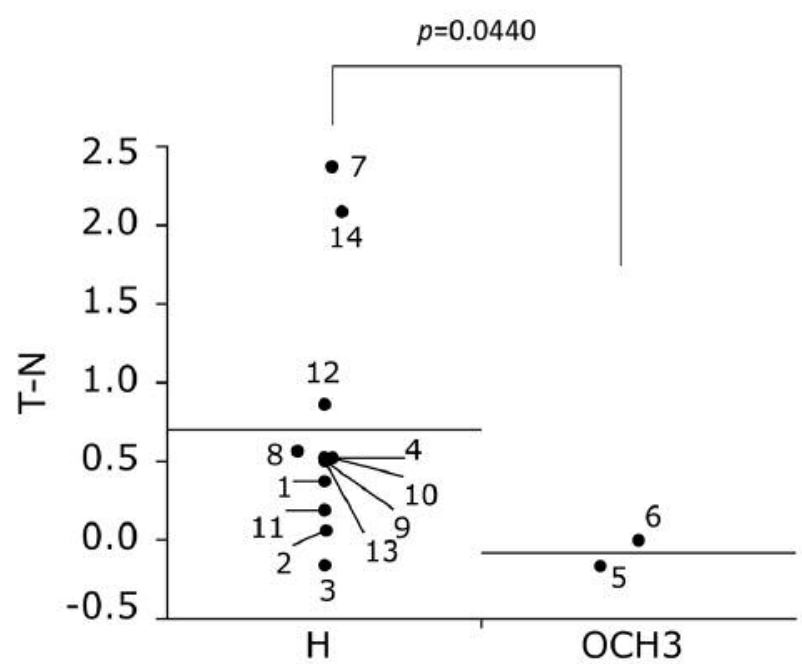

R1

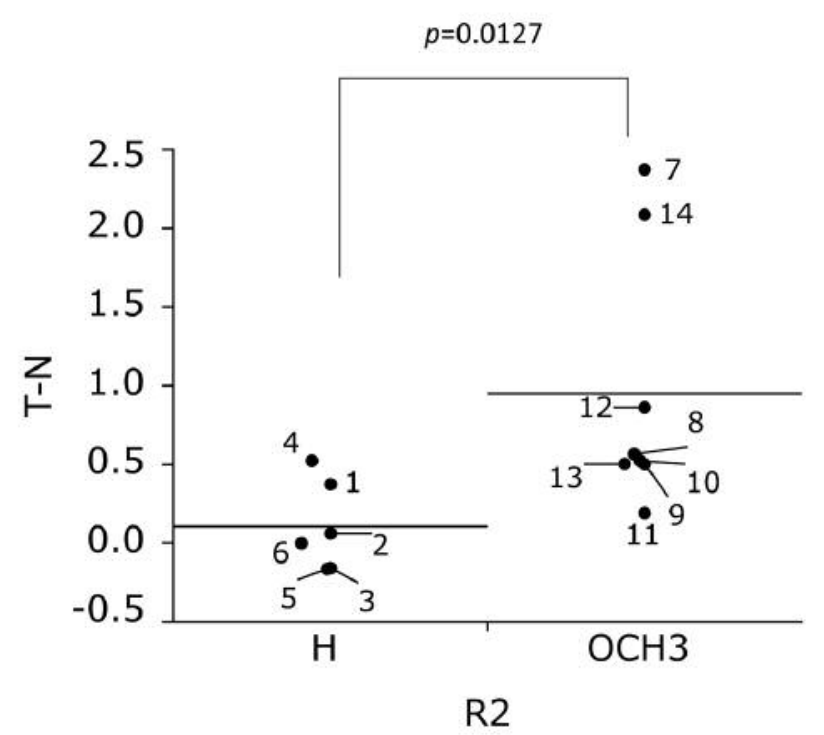

Figure 7. Correlation between $T-N$ and the presence of $\mathrm{OCH}_{3}$ group in $\mathrm{R} 1$ and R2. Statistical comparison between the means of two groups was performed by Wilcoxon exact test. The significance level was set at $p<0.05$.

Table II. Properties of descriptors that significantly correlated with cytotoxicity of fourteen 3-styrylchromones [1-14] against tumor cells (T) and normal cells $(N)$, and tumor-specificity $(T-N)$.

\begin{tabular}{|c|c|c|c|c|c|}
\hline & Descriptor & Source & Meaning & Category & Explanation \\
\hline \multirow[t]{2}{*}{$\mathrm{T}$} & PJI3 & Dragon & 3D shape and size & Geometrical descriptors & 3D Petitjean shape index \\
\hline & $\mathrm{CIC} 1$ & Dragon & Topological shape & Information indices & $\begin{array}{l}\text { Complementary Information Content index } \\
\text { (neighborhood symmetry of } 1 \text {-order) }\end{array}$ \\
\hline \multirow[t]{6}{*}{$\mathrm{N}$} & petitjean & MOE & $\begin{array}{l}\text { Topological shape } \\
\text { and size }\end{array}$ & $\begin{array}{l}\text { Adjacency and Distance } \\
\text { Matrix Descriptors }\end{array}$ & Value of (diameter - radius)/diameter. \\
\hline & SpMAD_AEA(dm) & Dragon & $\begin{array}{l}\text { Topological shape and } \\
\text { dipole moment }\end{array}$ & Edge adjacency indices & $\begin{array}{l}\text { Spectral mean absolute deviation } \\
\text { from augmented edge adjacency } \\
\text { mat. weighted by dipole moment }\end{array}$ \\
\hline & $\mathrm{BIC} 0$ & Dragon & Topological shape & Information indices & $\begin{array}{l}\text { Bond Information Content index } \\
\text { (neighborhood symmetry of 0-order) }\end{array}$ \\
\hline & MATS4s & Dragon & $\begin{array}{l}\text { Topological shape and } \\
\text { electric state }\end{array}$ & 2D autocorrelations & $\begin{array}{c}\text { Moran autocorrelation of lag } 4 \\
\text { weighted by I-state }\end{array}$ \\
\hline & MATS4e & Dragon & $\begin{array}{l}\text { Topological shape and } \\
\text { electric state }\end{array}$ & 2D autocorrelations & $\begin{array}{l}\text { Moran autocorrelation of lag } 4 \\
\text { weighted by Sanderson electronegativity }\end{array}$ \\
\hline & JGI8 & Dragon & $\begin{array}{l}\text { Topological shape and } \\
\text { electric state }\end{array}$ & 2D autocorrelations & Mean topological charge index of order 8 \\
\hline \multirow[t]{6}{*}{$\mathrm{T}-\mathrm{N}$} & MATS4e & Dragon & $\begin{array}{l}\text { Topological shape and } \\
\text { electric state }\end{array}$ & 2D autocorrelations & $\begin{array}{c}\text { Moran autocorrelation of lag } 4 \\
\text { weighted by Sanderson electronegativity }\end{array}$ \\
\hline & $\mathrm{H} 8 \mathrm{~s}$ & Dragon & 3D shape & GETAWAY descriptors & $\mathrm{H}$ autocorrelation of lag $8 /$ weighted by I-state \\
\hline & MNDO_LUMO & MOE & Energy of the LUMO & MOPAC Descriptors & $\begin{array}{l}\text { The energy }(\mathrm{eV}) \text { of the Lowest Unoccupied } \\
\text { Molecular Orbital calculated using the } \\
\text { MNDO Hamiltonian [MOPAC]. }\end{array}$ \\
\hline & AROM & Dragon & Aromaticity index & Geometrical descriptors & $\begin{array}{l}\text { The Aromaticity (AROM) is derived } \\
\text { from the scheme of the general } \\
\text { aromaticity indices. }\end{array}$ \\
\hline & FASA_H & MOE & $\begin{array}{l}\text { 3D shape, size and } \\
\text { partial charges }\end{array}$ & $\begin{array}{l}\text { Conformation Dependent } \\
\text { Charge Descriptors }\end{array}$ & $\begin{array}{c}\text { Fractional ASA_H calculated } \\
\text { as ASA_H/ASA. }\end{array}$ \\
\hline & $\mathrm{H} 8 \mathrm{e}$ & Dragon & $\begin{array}{l}\text { 3D shape and } \\
\text { electric state }\end{array}$ & GETAWAY descriptors & $\begin{array}{l}\mathrm{H} \text { autocorrelation of lag } 8 / \text { weighted } \\
\text { by Sanderson electronegativity }\end{array}$ \\
\hline
\end{tabular}


most potent compound [7] $(\mathrm{TS}=301.1)$ has methoxy group at 7-position and non-substituted styryl moiety, and replacing the methoxy group to 6-position yielded [5] with much reduced tumor-specificity $(\mathrm{TS}=0.8)$. This suggests that the introduction of methoxy group at 7-position is involved in the elevation of tumor-specificity.

QSAR analysis demonstrated that the cytotoxicity of 3styrylchromone derivatives [1-14] against OSCC cell lines was correlated positively with 3D and topological shape, and size (Figure 4). Their cytotoxicity against normal cells was correlated with topological shape and size, dipole moment and electric state (Figure 5). Their TS was correlated with 3D and topological shape, size, electric state, energy of the LUMO, aromaticity index and partial charges (Figure 6).

The present study also demonstrated that both $[7,14]$ produced a subG $\mathrm{s}_{1}$ cell population (a marker of apoptosis), and induced the accumulation at $\mathrm{G}_{2}+\mathrm{M}$ phase cells in human oral squamous cell carcinoma cell line HSC-2 (Figure 3). It has been reported recently that 4'-methoxy-2-styrylchromone induced mitotic arrest in human tumor (human Caucasian breast adenocarcinoma MCF-7 and human lung adenocarcinoma NCI-H460) cell lines, in a similar fashion to paclitaxel (15). It remains to be investigated whether mitotic arrest is common phenomenon after treatment with either 2-styrylchromon or 3-styrylchromone.

It should be noted that both $[7,14]$ induced apoptosis (subG ${ }_{1}$ population) of HSC-2 cells to comparable extent that attained by actinomycin $\mathrm{D}$, positive control used in this study (16). Induction of both apoptosis and $\mathrm{G}_{2}+\mathrm{M}$ arrest may further potentiate the antitumor potential.

We found that TS value (D/B in Table I) of two 3styrylchromones $[\mathbf{7}, \mathbf{1 4}](\mathrm{TS}=301.1,182.0)$ is much higher than the maximum TS values of 3-( $N$-cyclicamino)chromones (TS=12.3) (17), pyrano[4,3-b]chromones (TS=47.8) (18), 2arylazolylchromones and 2-triazolylchromones $(\mathrm{TS}=21.2)(19)$ and 2-styrylchromones ( $\mathrm{TS}=89.1)(20)$. This suggests that [7, 14] can be lead compounds for designing new types of anticancer drugs.

\section{Conflicts of Interest}

The Authors wish to confirm that there are no known conflicts of interest associated with this publication and there has been no significant financial support for this work that could have influenced its outcome.

\section{Authors' Contributions}

K.T., K.H. and Y.S. synthesized 3-styrylchoromones, H.S. and HX.S. performed cytotoxicity assay. K.B., A.T. and M.T. performed cell cycle analysis. J.N. and Y.U. performed QSAR analysis. K.T., H.S., Y.S., Y.U., A.T and M.T. authored and reviewed drafts of the article.

\section{Acknowledgements}

This work was partially supported by KAKENHI from the Japan Society for the Promotion of Science (JSPS) (15K08111, 16K11519).

\section{References}

1 Shimada C, Uesawa Y, Ishii-Nozawa R, Ishihara M, Kagaya H, Kanamoto T, Terakubo S, Nakashima H, Takao K, Sugita Y and Sakagami H: Quantitative structure-cytotoxicity relationship of 3-styrylchromones. Anticancer Res 34(10): 5405-5411, 2014. PMID: 25275035.

2 Sakagami H: Biological activities and possible dental application of three major groups of polyphenols. Review. J Pharmacol Sci 126(2): 92-106, 2014. PMID: 25263279.

3 Sakagami H, Watanabe T, Hoshino T, Suda N, Mori K, Yasui T, Yamauchi N, Kashiwagi H, Gomi T, Oizumi T, Nagai J, Uesawa Y, Takao K and Sugita Y: Recent progress of basic studies of natural products and their dental application. Review. Medicines (Basel) 6(1): 2018. PMID: 30585249. DOI: 10.3390/medicines6010004

4 Sonawane SA, Chavan VP, Shingare MS and Karale BK: Synthesis of 3-methyl-4-[(1,3-diphenyl-1H-pyrazol-4-yl) methylene]-1-phenylpyrazolin-5 (4H)-ones and some 3styrylchromones (Article). Indian J Heterocycl Chem 12 (1): 6566, 2002.

5 Conti $\mathrm{C}$ and Desideri $\mathrm{N}$ : New $4 H$-chromen-4-one and $2 \mathrm{H}$ chromene derivatives as anti-picornavirus capsid-binders. Bioorg Med Chem 18(17): 6480-6488, 2010. PMID: 20673722. DOI: 10.1016/j.bmc.2010.06.103

6 Takao K, Ishikawa R and Sugita Y: Synthesis and biological evaluation of 3-styrylchromone derivatives as free radical scavengers and $\alpha$-glucosidase inhibitors. Chem Pharm Bull (Tokyo) 62(8): 810-815, 2014. PMID: 25087634. DOI: org/10.1248/cpb.c14-00351

7 Sakagami H, Shimada C, Kanda Y, Amano O, Sugimoto M, Ota S, Soga T, Tomita M, Sato A, Tanuma SI, Takao K and Sugita Y: Effects of 3-styrylchromones on metabolic profiles and cell death in oral squamous cell carcinoma cells. Toxicol Rep 2: 1281-1290, 2015. PMID: 28962471. DOI: 10.1016/j.toxrep.2015.09.009

8 Shi H, Nagai J, Sakatsume T, Bandow K, Okudaira N, Sakagami H, Tomomura M, Tomomura A, Uesawa Y, Takao K and Sugita Y: Quantitative structure-cytotoxicity relationship of 2- $(\mathrm{N}$ cyclicamino)chromone derivatives. Anticancer Res 38(7): 38973906, 2018. PMID: 29970510. DOI:10.21873/anticanres.12674

9 Horikoshi M, Kimura Y, Nagura H, Ono T and Ito H: A new human cell line derived from human carcinoma of the gingiva. I. Its establishment and morphological studies. Jpn J Oral Maxillofac Surg 20: 100-106, 1974.

10 MarvinSketch 18.10.0. Available at: http://www.chemaxon.com (Last accessed on 16th October 2019)

11 CORINA Classic. Available at: https://www.mn-am.com/ products/corina (Last accessed on 16th October 2019)

12 MOE2019.0101. Available at: http://www.chemcomp.com/MOECheminformatics_and_QSAR.html (Last accessed on 16th October 2019)

13 Dragon 7. Available at: https://chm.kode-solutions.net/products_ dragon_descriptors.php (Last accessed on 16th October 2019)

14 JMP®. Available at: https://www.jmp.com/en_us/home.html (Last access on 16th October 2019) 
15 Marinho J, Pedro M, Pinto DC, Silva AM, Cavaleiro JA, Sunkel CE and Nascimento MS: 4'-Methoxy-2-styrylchromone a novel microtubule-stabilizing antimitotic agent. Biochem Pharmacol 75(4): 826-835, 2008. PMID: 18036572. DOI: org/10.1016/ j.bcp.2007.10.014

16 Sameni HR, Javadinia SS, Safari M, Tabrizi Amjad MH, Khanmohammadi N, Parsaie $\mathrm{H}$ and Zarbakhsh S: Effect of quercetin on the number of blastomeres, zona pellucida thickness, and hatching rate of mouse embryos exposed to actinomycin D: An experimental study. Int J Reprod Biomed (Yazd) 16(2): 101-108, 2018. PMID: 29675494.

17 Shi H, Nagai J, Sakatsume T, Bandow K, Okudaira N, Uesawa Y, Sakagami H, Tomomura M, Tomomura A, Takao K and Sugita Y: Quantitative structure-cytotoxicity relationship of 3-(Ncyclicamino)chromone derivatives. Anticancer Res 38(8): 44594467, 2018. PMID: 30061210. DOI: 10.21873/anticanres. 12748

18 Nagai J, Shi H, Kubota Y, Bandow K, Okudaira N, Uesawa Y, Sakagami H, Tomomura M, Tomomura A, Takao K and Sugita Y: Quantitative structure-cytotoxicity relationship of pyrano[4,3$b$ chromones. Anticancer Res 38(8): 4449-4457. PMID: 30061209. DOI: 10.21873 /anticanres.12747
19 Nagai J, Shi H, Sezaki N, Yoshida N, Bando K, Uesawa Y, Sakagami H, Tomomura M, Tomomura A, Takao K and Sugita Y: Quantitative structure-cytotoxicity relationship of 2arylazolylchromones and 2-triazolylchromones. Anticancer Res 39(12): 6479-6488, 2019. DOI: 10.21873/anticanres.13862

20 Uesawa Y, Nagai J, Shi H, Sakagami H, Bandow K, Tomomura A, Tomomura M, Endo S, Takao K and Sugita Y: Quantitative structure-cytotoxicity relationship of 2-styrylchromones. Anticancer Res 39(12): 6489-6498, 2019. DOI: 10.21873/anticanres.13863

Received November 20, 2019

Revised November 26, 2019

Accepted December 2, 2019 